\title{
Legal Reform on Property Restitution and Compensation and the Perspective of the European Integration of Albania. (Review of Legal Framework)
}

\author{
Bledar Abdurrahmani \\ University "Aleksandër Moisiu", Durrës \\ E-mail: bledar_abdurrahmani@yahoo.com
}

\author{
Doi:10.5901/ajis.2012.v2n4p11
}

\section{Abstract:}

During the last 20 years, a large number of expropriated subjects were entitled the right for property compensation. Although many years have passed since then, the titles which recognize the rights for property compensation have remained unexecuted. The lack of a concrete and realistic scheme which is based on the principle of suitable compensation, equal treatment and proportionality has turned the attained property rights into an illusion. Therefore, any expropriated subject may reasonably raise the following questions which constitute the foundation of this study:

- When will the property compensation be achieved considering that the law does not foresee it?

- Should the law offer clear specifications?

- What does the application for financial compensation mean according to the rules and criteria layed down by the Council of Ministers, and when the compensation is obtained when will the remaining part be issued?

- Is such a regulation legal (constitutional)? Thus, does this regulation comply the constitutional principles?

Being focused on finding a solution to the property compensation issue, this study analyses some of the main legal institutions foreseen by the legislation in this field from year 2004 up to nowadays. A specific attention is given to the current compensation scheme and its legality from the perspective of the constitutional assurances, ECHR practices and constitutional jurisprudences of other countries. Firstly, this analysis aims to identify the theoretic guarantees provided by the law and how effective is such implementation in practice. The study modestly strives to answer to the aforementioned questions by examining the main problems highlighted during this process. It also aims to sensibilize the actors of the system which are seriously committed to carry out the necessary changes to provide solution to the land ownership as one of the main political, legal, economic and social challenges faced by the Albanian state.

Keywords: Property Rights, Legal Reform, Property Restitution and Compensation Process, European Integration, European Convention on Human Rights.

\section{Introduction}

The following study is a review of the legal framework and reforms undertaken in the field of the property restitution and compensation in the context of Albanian perspective towards European Union integration. This study is organized in four topics, based on the analysis of basic domestic and international legal documents which guarantee the private property right. The work is also based on the examination of the European literature regarding property issues, jurisprudence of the European Court of Human Rights, and our domestic or other countries' constitutional jurisprudences. The topics of this study examine the property right as a basic human right, the role of the law in the societies and countries in transition and restoration of the private property right in Albania, legal reforms in the field of property restitution and compensation carried out during these years, as well as, the efforts for resolving the property compensation issues.

During the last 20 years, a large number of expropriated subjects were entitled the right for property compensation. Although many years have passed since then, the titles which recognize the rights for property compensation have remained unexecuted. The lack of a concrete and realistic scheme which is based on the principle of suitable compensation, equal treatment and proportionality has turned the attained property rights 
into an illusion. Therefore, any expropriated subject may reasonably raise the following questions which constitute the foundation of this study:

- When will the property compensation be achieved considering that the law does not foresee it?

- Should the law offer clear specifications?

- What does the application for financial compensation mean according to the rules and criteria layed down by the Council of Ministers, and when the compensation is obtained when will the remaining part be issued?

- Is such a regulation legal (constitutional)? Thus, does this regulation comply the constitutional principles?

Being focused on finding a solution to the property compensation issue, this study analyses some of the main legal institutions foreseen by the legislation in this field from year 2004 up to nowadays. A specific attention is given to the current compensation scheme and its legality from the perspective of the constitutional assurances, ECHR practices and constitutional jurisprudences of other countries. Firstly, this analysis aims to identify the theoretic guarantees provided by the law and how effective is such implementation in practice. The study modestly strives to answer to the aforementioned questions by examining the main problems highlighted during this process. It also aims to sensibilize the actors of the system which are seriously committed to carry out the necessary changes to provide solution to the land ownership as one of the main political, legal, economic and social challenges faced by the Albanian state.

\section{Property right as a fundamental human right}

In today's modern state, the property is one of the key concepts of the legal system. The conventional meaning of the property represents the relation or the close link between a person and an object (or right). According to the general understanding, property means a material or non-material object which is established or obtained by a person according to the regulations stipulated by law. This person is free to determine the fate of his object such as when and how this object will be used within the limits foreseen by the law and any third person has the obligation to respect the right of the owner over his object by not perfoming actions that infringe this right. Property right is 'the right of each person to freely enjoy and make available his objects within the limits stipulated by the law"(Kodi Civil, 1994: 149). The property, together with the binding contract is the foundation of any trade exchange or business activity being the basic elements over which the market economy is established. Therefore, in a free and developed social and economic order, property right constitutes one of the fundamental human rights. In this way it stands as the basis of the human existence by being the most essential factor of the prosperity, social welfare and freedom of person and society. The importance of freedom and justice in democratic societies does not have any meaning without a genuine safeguard of the property rights. Recognition, development and protection of the property rights contribute to safeguarding the political, economic and social stability. Through the 'recognition of the private property' the democratic state provides the possibility for the people to acquire a property from the persons while at the same time it accepts and gurantees the right for private property ownership.(Rawls, 2001:138)"

Since the Ancient Rome period, the property right was considered as one of the most fundamental human rights. It was composed by a set of everlasting prerogatives such as:"jus utendi, fruendi, abutendi, possidendi, alienandi, disponendi, vindicandi". According to the Roman Law doctrine (Benussi, 1931:33), property right did not represent the sum of all the prerogatives, but the unity of all the powers attributed to the title-bearer. It did not consist of a series of certain rights, but of the overall power which encompasses in it any prerogative that can be thought about. In this context, the property right is considered closely connected with the person and his personality.

In his book 'Summa Theologica', Thomas Aquinas considered property as an important incentive for the human being which keeps him connected with his duties and brings him beneficial effects for a harmonious co-existence in the society (Acquinas, 1947:32). According to Cheneval (2006:41), private property is closely connected with the person, his body, mind and activities, the space he occupies and needs, the things he 
uses and the work he performs. Therefore, private property is closely linked with the need and ability of the person to make a living through the opportunity given and through his activities and works in order to freely own objects and rights. The inherent need of the person to gain as many property rights as possible is an important part of the freedom of persons to act in society and preserve their personal integrity. As such, the property right has a profound economic character and it serves to the prosperity of the person in society. At the end of the day, any objective or claim of the person is above all directed towards a concrete object (material or non-material) which constitutes a property right. In this view, the private property right is directly connected with the personality of the person and established responsible and dignified relation and places the person in an independent position form other people. Stimulation and protection of this right of general character creates positive premises in the society not only in the economic perspective but also for the creation and development of moral values for each person. Therefore, guaranteeing and protection of the private property right is directly linked with respect towards the integrity of the human being.

The private property right is one of the fundamental rights and plays an essential role in the efficient fulfilment of the social justice and freedom of person in the rule-of-law state. Denial of this right at any stage of the social and political development is characterized by great social injustices and violation of basic human rights and freedom. This right has profound inherent character and does not originate from the positive right and, as such, it has preceeded any form of political or legal development in the society. Historically, the private property right is considered as the main paradigm for other rights in general. Boyce expressed that 'in any social organization, the property constitutes a basic prerequisite for creation and existence of the free initiative and private activity, thus creating the foundations of a free and democratic system.(Boyce, 2007: 29)"

The duty of any government is to endorse a system of legal rules which strongly supports the recognition, development and protection of the private property and freedom of economic activity. The state must establish the appropriate mechanisms which enable the development of the private property as the only way which fully ensures the citizens the improvement of their life through work and free activities, mainly in the private sector. The private property as a fundamental right imposes the state authorities the establishment of a functional and efficient framework, offering equal opportunities to obtain and establish a property without any racial prejudices, sexual orientation and other social differences. Therefore, the establishment of a property right system in accordance with the best international standards is an indispensable requirement for the existence of the rule of law. A legal system which ensures the private property right and which sets a fair and proportional relation between the need of the state authorities for restricting the property right and the citizens' interest, by also enabling a fair compensation (in case of expropriation or restriction of such right), it fully serves to the prosperity of the person, peace, alleviation of property, economic development and social justice. The implementation in practice of those principles provides enormous benefits to the society, state and the citizens.

Therefore, based on these great values for the person and society, the positive domestic and international law has paid special attention the right to obtain and freely own a property. The Universal Declaration of Human Rights constitutes the basic international document which proclaims the fundamental rights that any person enjoys in a society and which sets the basic standards for respecting these rights by any person or social organization. An essential part of this declaration is the affirmation and protection guaranteed to the property right. According to Article 17 of this Declaration (1948): "Everyone has the right to own property alone as well as in association with others. No one shall be arbitrarily deprived of his property". The European Convention for Protection of Human Rights constitutes another important document of international level. According to this Convention: "Every natural or legal person is entitled to the peaceful enjoyment of his possessions. No one shall be deprived of his/her property possessions except in the public interest and subject to the conditions provided for by law and by general principles of international law". The jurispendence of the European Court of Human Rights constitutes another important source by giving the true meaning to the protection guaranteed by the Convention. The private property right provides full support even in the domestic law. The Constitution of the Republic of Albania (Kushtetuta,1998: article 18,41) guarantees the private property right. According to this "the economic system is based on private and public property as 
well as on market economy and free economic activity. Expropriations or restrictions in exerting the property right are allowed only for public interests and only against a fair compensation." The basic legal documents guarantee any entitled subject the opportunity to have a property. These acts sanction that the property right is an undeniable right and this cannot be affected by public interest without prior implementation of the strict procedural regulations defined by law for fair compensation.

\section{The role of the property right under the transition period in the society. Restoration of the private property right in Albania through property restitution and compensation process}

During the transition period, the role of the law, on one hand is to overcome the previous conventional rigid boundaries and on the other to aim towards a radical political, legal, economic and social transformation. The process of transformation from a bitter past to a better future is followed by an internal conflict of values. The special political and historical circumstances determine the new values that must be protected and the social importance they have, in order for the transition to guarantee the efficient functioning of the selected values and fulfilment of the social objectives. In the democratic state, the value of social justice constitutes one of the main pillars of its functioning. This basic value of the rule of law is embodied in the social state principle.

The post-communist states were faced with the dilemma of restoration of social justice. In order to ensure the efficient implementation of the social justice principle, the post-communist states have recognized the human rights violation under the communist regimes, commitment of crimes for political ends, or even the violation of the core function of law in society by transforming and using it as an instrument for justifying the communist crimes. The process of facing the past is extraordinarily difficult for a democratic society. This is based on the fact that adjustments by law of issues which have occurred in the past, due to their retroactive nature, bear always the risk of not finding the right balance between the values we seek to protect and the interests that could be affected, thus often being a subject to the the constitutional control. The law is the only instrument which serves not only to acknowledge and ideologically punish the crimes and social injustice of the communist dictatorship, but also to reinstate effectively the social justice. The regulation by law of the land property right constitutes an indispensable part of the transition from the past communist legal system and its property regime to a new system which is compatible with the rule-of-law and market economy.

In fact, the catastrophic blow that the private property right received under the communist regime in Albania was not the only one, and not the most powerful one, in terms of the damage caused to the basic human rights in this period. During the dictatorship built on grounds of "class struggle", atheism and common socialist property, a large number of people were declared "enemies" thus depriving them of the basic right to which each person is naturally entitled to have such as, the right to live, fredom, free movement, freedom of speech, creed, etc. The brutal dictatorship established a new large category of expropriated people whose properties were nationalized, expropriated or confiscated based on legal acts, sub-laws, court penal decisions, or other unjustified means. The eradication of the property rights has caused enourmous social shock. Therefore, reinstatement of a basic right under the framework of a new philosophy of the rule of law was an indenspensable measure to gurantee social justice.

According to the constitutional laws:

The process of restitution and compensation of the property in Europe emerged as a need to establish social justice because persons were stripped from the property according to the previous regime legislation, but it was inconsistent with the basic rights elements of the democratic countries where the private property right is recognized and protected by the legal order. In such conditions, persons who were deprived from the property rights during the totalitarian regimes bore the right to obtain the same legal position with regard to the property as they had been before the nationalization process.(Vendim Gjyk.Kushtetuese, 2010:27)

In 1993, Albania adopted a new legal framework which guaranteed the recognition of the private property right for those subjects whose property was expropriated, nationalized, confiscated or taken away through any unjustified means by the state. The process of recognition, restitution and compensation of 
property was based on two basic principles: fairness and legality. First, the objective of this process is correction of the past injustice; and secondly, it was the consolidation of a new philosophy based on the values of the new democratic system and rule of law.

According to the Czech constitutional law: 'in the social state, the implementation of the social justice principle for each case must be valued as closely related with the public interest and for the benefit of any person in the society. Reinstatement of the social justice cannot cause any other injustices"(Vendim Gjyk.Kushtetuese Ceke, 1998:P1.US1/98). The state, as a warrantor of the common benefit, has therefore the full discretion to determine the measure, method, form and procedures for restitution and compensation of the property to the expropriated subjects. This is viewed as closely related with the possibility to effectively carry out the restoration of property rights without causing other economic and social problems. The application of the social justice principle in all the adjustments of retroactive character, particularly in the process of restitution and compensation of the property, must be viewed closely related to other bacis principles of the rule of law which are extensively addressed by the ECHR law and to a lesser extent by the constitutional court law (in the first years of democratic transition). This has had particular importance in the circumstances when the process of recognition, restitution and compensation of the property aimed not only to strip the state from the property right over the immovable property but also from those private persons who were granted the rights over the properties of the expropriated subjects under the communist regime ${ }^{1}$. The principle of justice seeks to consider the proportionality principles, thus not only the interests of the expropriated subjects and their heirs, but also of other members of society, as well as the public interest in general (Gjykata Kushtetuese,2005:30). Therefore, the intervention of the legislator to the property right could be justified only if it serves to a legal objective for the benefit of public or general interests. According to Frisk (Carss, Frisk 2001:art.1 prot.), the acquitance of a property based on a thoughtful policy in order to attain the social justice within the community may be fully justified as a policy undertaken for the public interest.

According to the international law, there is no obligation which imposes the countries to restitute or compensate the loss of the property rights that people have been inflicted under the previous regimes (Kuti, 2009:37). In year 1994 the Constitutional Court of Republic of Albania, by request of the expropriator's Association for Ownership with Justice, has expressed the following statement through a request with subject repeal of Law no. 7561 dated 19.07.1991 'On Land', Law no. 7699 dated 21.04.1993 'On compensation with monetary value of agricultural land ex-owners' as well as the repeal of some provisions of Law no 7698 dated 15.04.1993 'On restitution and compensation of the properties to ex-owners':

[... ] the democratic state, although was not and cannot be responsible for the nationalization, confiscation, expropriation of property or taken arbitrary with any other method by the communist dictatorship state, assumed the legal obligation to recover, within its objective capacities, these type of injustices commited from 29.11.1944 up to the collapse of the monist state.(Vendim Gjykate Kushtetuese,2005:30).

According to the ECHR jurisprudence, the governments have the full discretion to take decision on issues which are considered that they serve to the restoration of the social justice. The ECHR has expressed their stance as follows:

[... ] the Convent cannot be interpreted as imposition of a general obligation over the Contractual Countries for returning the transferred property to their favour, prior to ratification of the Convention. According to the Convent, there is no general obligation for establishing the procedures to seek the restitution of the property. Nonetheless, when a Contractual Country decides to establish legal procedures of such type, it cannot be exempted from the obligation to respect all the respective assurances foreseen by the Convent, particularly in

\footnotetext{
${ }^{1}$ Look at article 1, 10,11, 12 dhe 13 of the law nr.7698, date 15.04.1993 "About the restitution and compensation of land to ex owners.".
} 
article 6 § 1."( Beshiri vs. Shqipërisë No 7352/03 § 61 Kopecky v. Slovakia [GC], No 44912/98, § 35 dhe von Maltzan and Others v. Germany (dec.) [GC], No 71916/01, 71917/01 dhe 10260/02, § 74, ECHR 2005-V.)

When a Contractual Country, which has ratified the Convention, including the First Additional Protocol, adopts legislation which regulates full or partial restitution of the property confiscated during the previous regime, this legislation may be considered as a generator of a new property right, and therefore all the persons who meet the requirements to obtain such a right are protected under article no 1 of Protocol no 1 of the Convention (Broniowski vs.Poland, 2004).

\subsection{The Process of recognition, restitution and compensation of the property and privatisation}

The process of restitution and compensation of the properties cannot be viewed out of the political, economic and social context of the prolonged transition of the country. During the transition period, the post-communist countries had two main objectives: restoration of the social justice and establishment of the conditions, standards, finding of required mechanisms to provide great impetus and speed to the privatisation of the economy and renewal of the private property right. In this view, the process of recognition, restitution and compensation of the properties embodies itself two mains aspects, 'distributive' and 'reparative' character (Hayek, 1991:59)". The property rights in Albania underwent a dynamic process which included massive legislative and institutional transformations highlighting the need for establishing a suitable balance between the individual rights and collective rights (VKM 2012:405). In this context, legal adjustments in the field of property ownership over the agricultural land had transitional but not fundamental characteristics.

The establishment of the social justice in the field of restitution and compensation of the properties in Albania not only had an economic character. It should not be seen as structural economic reform which aimed to pass the property rights from the state to the private subjects, and not as a way to punish the previous ruling elite and the state officials. The true value of this reform lies in the new philosoply which led the Albanian legislator towards the establishment and consolidation of the rule of law. This reform fully materializes constitutional guarantees (Ligji per dispozitat kryesore kushtetuese, 1991:7491/1,2)proclaimed by the new democratic state for recognition and protection of the basic human rights and liberties and restoration of social justice.

At first sight, it seems that the fulfilment of the two objectives could be easily accomplished because they were considered as part of a unique process 'stripping the state form the property right, regardless whether the property right over the state property would be transferred through privatization procedures to the respective subjects or returning the property to the expropriated subject. Moreover, the transfer or allocation of the property right from the state to the previous owner, in fulfilling the social justice principle, in parallel with the process of privatization of the economy (factories, shops, apartments, etc), would have had positive impact to the development of the free market economy. The parallel development of the two processes, not only did not serve to the restoration of the private property right, but presented many conflicts and disputes resulting in high costs for the persons, state and the property right itself. During this period, the object of the constitutional jurisdiction, with regard to setting a fair balance between privatization process and restitution and compensation process, has often been the provisions of the Act 'On restitution and compensation of the property"2.

The main issue which influenced the large number of disputes regarding the property rights over the agricultural land was the lack of a unified legal framework. The legal regulations undertaken to guarantee the functioning of the democratic state and give impetus to the transferation of private property from the state to the persons has often been in conflict with each other or with the basic principles of the property rights. At this

\footnotetext{
${ }^{2}$ We mention Verdict nr.4, date 08.04.1994, Fletore Zyrtare. nr.5, Fq 284, and verdict nr. 7 date 14.09.1994 of the constitutional court of Albania.
} 
period, the legal acts were scattered, the number of state authorities producing ownership titles was enormous and their activity was uncoordinated, the legal means which carried out the establishment of compensation right were not effective and, in general, they did not guarantee the restoration of the justice through an appropriate legal process.

\section{Legal reforms in the field of recognition, restitution and compensation of the property}

The modification of the Albanian legislation in the field of restitution and compensation of the property in year 2004 was a result of the obligation imposed to the Albanian Parliament by the Constitution of the country. The big blow received by the private property right and the large dimension of this fenomenon in the Albanian society had sensibilized constitutional lawmakers to give this problem a particular importance.(Kushtetuta e Shqiperise, 1998:art.181) In fact, such an obligation, in the constitutional dimension, was not foreseen in any of the East and Southeast European countries. A considerable influence in this respect has had the assessment of different practises of other post-communist countries in adjusting the relevant legislation, and compliance with standards of the European Court of Human Rights laws.

The complexity of this process, the large number of the requests submitted (but still unprocessed) regarding the recognition, restitution and compensation of the property, standardization of decision making, aforementioned problems which have emerged during the implementation of this process during a transitional period of political, economic, legal and social development of the country, as well as the non-fulfillment of the compensation right of the property against the expropriated subjects were the main reasons for making a new regulation. The affirmation of the rule of law required that this complicated process must be carried out according to the principles of basic rights such as: taking into consideration the public interest against the restoration of the private rights for the expropriated subjects and setting a fair compensation for properties that would be compensated to those subjects.(Law 9235,2004:art.1).

The approval of Law no. 9235 dated 29.07.2004 'On restitution and compensation of the property' constitutes a step forward not only towards complying with the standards regarding the request for recognition and compensation of property, establishment of specialized administrative authorities dealing with processing those requests, increase of the size of restitution and compensation of property(ibid, art. 6/1), coordination of the administrative activity with other actors in other fields of land rights, but most important, it seemed that the law offered full assurances regarding the compensation of the property.

\subsection{The property compensation right}

It is now acknowledged the position of the ECHR and Constitutional Court that the property right cannot be identical with the restitution right. This is because article 1 of Protocol 1 (Addendum) of the European Court of Human Rights protects only the existing properties and does not guarantee the right to acquire properties. This assessment is based on the principle that the conviction for the existence of the property right which was used ineffectively for a long time does not constitute a property (Carss-Frisk, 2001:67). Therefore, the concept of property includes that which is acknowledged and returned for good through an administrative or court decision. In this meaning, ECHR states that article 1 of Protocol no 1 protects not only the current properties, but also the future ones. In order to define the nature of the property according to article 1 of Protocol 1, the Court has expressed that the term property includes the claims for compensation of the expropriated property (Gomien, 2005:24).

The restoration of the social justice means not only the restitution of previous properties, but also its compensation in case when it cannot be returned physically. The compensation according to the concept of the law for restitution and compensation of the property is the only form of reparation (in lieu) or compensation 'for the damage' caused to the expropriated subject from the previous government. Compensation in full value of the property to the legal owner aims to fully rehabilitate the consequences of the unjust practices. The right for compensation, although is a loan right, the origin and the foundation of it is based on the genuine property 
right over the plot of land that cannot be returned to the ex-owners only because it is considered as occupied by the law (High Vend. Gjykata e Larte, 2007:6). Therefore, this is a right of the expropriated subject or his inheritors against the state. This right is presented as the right of persons (owner or inheritor) against state obligations for a certain attitude, which includes the obligation for compensating their property. At the moment when such right is borne, the High Court emphasizes that this right is obtained with the presentation of the decision for the compensation of the property, and it means that the state undertakes to carry out the defined obligation in future (V.Unif. Gjykata e Larte nr.23, 2002).

\subsection{Aspects of property compensation}

The legal reform on restitution and compensation of the properties in year 2004 consitutes the first concrete step towards the regulation by law of certain aspects and legal institutions related to the compensation of property. For the first time, the law defines the meaning of compensation as fair reward calculated according to the market value at the moment of recognition of such compensation.(ibid, article 1). Different from the previous law, the law of year 2004 did not define whether the state is commited to offer a full service for the expropriated subjects, but it emitted the constitutional concept of fair compensation. In order to determine the value of the property which is compensated according to the market value, it was necessary to have a methodologic handbook (ibid,13:2) which contains the respective formulas according to which it will evaluate the compensation for different types of properties, according to specific cadastral items, such as plot of land agricultural land, forest, meadow, pasture, etc. This methodology regardless of the detailed technical aspect it contained would be ratified with a Parliament decision, as the highest form of the leadership activity in the rule of law state. (Vendim 183, 2005, 219). One of the warranties the law offers is that the expropriated subjects, from the period from the recognition of the property right until acquisition of the compensation in form of monetary reward, also receive the bank interest calculated accoding the annual average published by the Bank of Albania.(Ligji 9235,2004:23/2)

Another innovation of the law is profiliration of the property compensation forms, by establishing new compensation forms that apparently presented a genuine warranty for the expropriated subjects. The previous experience has shown that the compensation with state bonds did not have the efficacy not only for their issuance but also in prioritising the expropriated subjects in the privatization of the state assets. Meanwhile, the compensation with equivalent or touristic properties, where it was implemented, produced great disconsent to the expropriated subjects and possibility for abuse in the conditions of lack of equal criteria for distribution of compensation and based on a fair and modern methodologic assessment according to which it would evaluate the value of property entitled for compensation against those who will be compensated.

Now, the law defined clearly two main compensation forms, physical and financial. To ensure the efficiency of those compensation forms, a physical and financial compensation fund was established.(Ligji $9235,2004: 23 / 28)$. The physical compensation concept included the compensation with another immovable property of the same type, or any other type, of equal value owned by the state, as well as, other state properties located in areas that have priority the touristic development, inside or outside the district boundaries. In the assessment of the lawmaker, it was necessary to provide a preliminary definition of a specific regulating framework which would sanction the criteria and procedures it would 'fill in' the physical compensation fund(ibid, article 12). In this aspect, it was very necessary to define which of the land categories would constitute the physical compensation fund; the criteria that would serve to identify the state properties; the state authorities that administer those properties; and the relation that would be established between those authorities and the authority in charge to carry out the physical compensation in the preliminary verification phase.(VKM 567, 2007). Following the identification of those state property funds, based on a decision of the Council of Ministers, they would be allocated to the physical compensation fund with the purpose to distribute them in favour of the expropriated subjects according to the rules and criteria defined by the Council of Ministers. 
The financial compensation (or in value) meant compensation with companies that state capital shares or when the state is co-owner (the shares have same value with the property), with the value of the object which are issued for sale during the privatization process, as well as in cash. According to the law, the Council of Ministers is charged with the obligation that, for 10 consecutive years, to foresee in the state annual budget a specific fund for monetary compensation of the expropriated subjects. This capital would be allocated to the financial compensation fund. Any income that will be obtained from the sale auction of state properties, or from a possible donator, would be added to this fund. The notion of financial compensation would be significantly reviewed in year 2010 when the lawmaker decided to consider this fund as special in the meaning of Law no 9936 dated 26.6.2008 'On managing the budgetary system of Republic of Albania'. In essence, this law aimed to establish a regulation of economic and financial character which authorised the transferation of the financial compensation fund to the next annual budget, if the fund is not used (or is surplus) during the calendar year. So, the sources which would supply the financial compensation fund are incorporated in the law.

The physical compensation fund constitutes an immovable property fund of state ownership that would be available, within a set time, to the respective executive authorities of Council of Ministers for carrying out the physical compensation process. In 2008, the Council of Ministers allocated an immovable property fund including agricultural land, forests, pastures and other state objects which were transferred to the physical compensation fund ${ }^{3}$. However, one the one hand, it was (and still is) the duty of the administrative authorities dealing with restitution and compensation of the properties, in collaboration with a number of public agencies, to perform the final verification of the legal status of the property, by deducting from the fund those properties which result as privately owned. On the other hand, those authorities must verify, assess and identify each property prior to commencing the physical distribution and compensation process. Carrying out such a process of verification and assessment has been impossible due to the insufficient number of human resources at a local and national level available at PRCA and based on the wide scope of the activity to be performed.(VKM 9235, 2005 and VKM 556, 2006).

Assessing that the process of non implementation of the decisions for recognition, restitution or compensation of the properties has increased enormously, the legislator made a step forward by giving additional legal assurances to the expropriated subjects. Hence, the final decision for recognition, restitution and compensation of the property is considered as an executive title and the Bailiff Office was charged for their execution according to the rules of the the Code of Civil Procedures(Ligji 9684,2007:art. 1/2).

\subsection{Procedures for property compensation}

The law for restitution and compensation of the property intended to provide a suitable solution for the decisions given in the previous years but had remained unexecuted for years.(Law 9235, 2004:22) With the main purpose to ensure the physical restitution of the property to the maximum level and the restoration of the property rights over the land, the lawmaker, with the new amendments to the law, removed the limit regarding the amount of restitution of the land category plot of land and enabled the expropriated subjects that with a new request (unaccompanied with other acts, because they had to exist in the previous file) to request the adequate administrative authority for recognition, restitution and compensation of the remaining unprocessed

3 VKM nr.868, datë 18.06.2008 "Për krijimin e fondit të kompensimit fizik nga fondi i tokës bujqësore", Flet.Zyrt. nr.138. Fq 6123.

VKM nr.1077, datë 18.06.2008"Për krijimin e fondit të kompensimit fizik nga fondi pyjor dhe kullosor", Flet.Zyrt. nr.129, Fq 5707.

VKM nr.1232, datë 18.06.2008"Për krijimin e fondit të kompensimit nga objektet shtetërore", Flet. Zyrt. nr.147, Fq 7264.

VKM nr.1696, datë 24.12.2008 "Për krijimin e fondit të kompensimit fizik, nga objekte shtetërore të "Albminiera"sh.a, dhe të Shërbimit Gjeologjik Shqiptar", Flet. Zyrt.nr.206, Fq 11089. Sipas këtij akti kalojnë në fondin e kompensimit fizik 32 objekte. 
properties. Meanwhile, for decisions which acknowledged the property right to the expropriated subjects for other types of property and were not executed, the law authorised the competent authorities to assess whether it was possible the physical restitution or compensation of the property. The whole process of recognition, restitution and compensation of the property would resume in the form, method and conditions foreseen by the new law. By considering as unconcluded the process of restitution and compensation of the properties, the legislator, through the aforementioned legal definition, with retroactive character, undertook the responsibility to also resolve the issue of compensating the property for the expropriated subject, whose requests were processed under the previous law, but the respective decision (which acknowledged the right for compensation) was not implemented yet.

Thus, the process of executing the decision (current and previous) of property compensation would be carried out, according to the legislator, through a specific administrative procedure. This intended that not only the expropriated subjects, whose properties were acknowledged for compensation according to the preivous law (Act no 7698/1993), would re-apply the execution of their decision, but those subjects whose properties would be processed based on the provisions of the new law, also had to resubmit their request for compensation to the same administrative authority. The expropriated subjects have the duty to submit a request for compensation of their property which must be processed within 3 months (from the date of its submission).(ibid article 17/2). However, the submission of this request cannot be done at any time, but only at the moment when a concrete compensation fund exists and only when the rules and criteria for its distribution are defined. The law authorizes the Council of Ministers to define the rules and criteria for processing the decisions for financial compensation, procedures which must be completed within first six months of each financial year. The law provides the premise for the expropriated subjects that the whole financial compensation process will be completed within 2014, while there was no concrete forecast with regard to the physical compensation process. During these years, some financial compensation processes have taken place,(VKM nr.758/2006; nr.566/2007; nr.1343/2008; nr.478/2009; nr.192/2011)while almost nothing is done with regard to the physical compensation process. The financial compensation procedure was characterized by very restrictive rules and only a small number of subjects have obtained financial compensation. During these years, the monetary fund available for the process has been very small.

\subsection{Issues related to the property compensation process}

During the 20 years period, a large number of expropriated subjects were granted the right to property compensation. Although many years have passed since then, the titles which acknowledge the right to property compensation have remained unexecuted. The lack of a concrete and realistic scheme which is based on the principle of fair compensation, equal processing and proportionality, has turned the granted rights for the expropriated subjects into illusion. Therefore, each expropriated subject logically makes some questions. When will the compensation right be fulfilled, in the conditions when the law does not offer any answer? Should the law be silent for this issue by not defining anything tangible? What does the application for financial compensation means accoding to the rules and criteria defined by the Council of Ministers decision and if the compensation is granted when will the remaining part be delivered? Therefore, is it legal (constitutional) such a regulation, thus how much it complies with the constitutional requirements and principles?

In the field of property, this issue has increased significantly the number of requests addressed to, and continues being addressed to the ECHR and it constitutes a major concern for finding a solution for land property issues. The Court has reviewed many complaints related to the difficulties in receiving the compensation for private properties. According to the viewpoint of the Court, in order to assess whether certain government measures fulfil the standards set by article 1 of Protocol no 1, the Court takes into consideration the following factors: the complexity of laws and procedures which regulate the expropriation and compensation, the duration of the procedures, the damage which results from the duration of the privation 
and insufficient amount of compensation, by taking into consideration the delays in payment (Gomien, 2005:41).

This study modestly strives to provide answers to the above questions by analyzing the main issues identified under the framework of property compensation process. The study also aims to make aware the actors of this system who are seriously commited to carry out the necessary modifications in order to provide a solution to the land ownership issue being one of the major political, legal, economic and social challenges that the Albanian state is facing.

One of the main faults of the law is that on one hand it acknowledges and accepts the right for property compensation, while on the other hand does not foresee any concrete measure when such right will be fulfilled. The commitment of the legislator for full compensation of the property serves better to the full reparation of the damage inflicted to the expropriated subjects. In order that the legal promises are convincing in theory, they must necessarily be accomplished with required legal means which enable their application in practice. Without this assurance, which is the responsibility of the state to ensure, these means cannot be exhausted according to the needs and would remain ineffective (Beshiri against Albania 7352, 2006:52). In fact this coherent approach of the Albanian legislator has not yet been reflected with concrete theoretical and practical measures in the law, by jeopardizing the expectations of the expropriated subjects and turning the obtained rights into illusions. According to the jurisprudence of European Court of Human Rights, the member states have the obligation to take all the necessary measures for effective execution of a basic right such as the property right. According to the view of ECHR, the rule of law principle and legality principle under the standpoint of article 1 of Protocol 1 of the European Convent of Human Rights requires the member states not only to comply with and implement in coherent way the adopted laws, but also to guarantee, with regard to this obligation, the legal conditions and practices of their implementation. These principles require the fulfilment in timely, correct and coherent manner all the legislative promises (Beshiri kundër Shqipërisë, 2006:58).

Is constutionally legitimate the current scheme of financial compensation carried out by the authorities of restitution and compensation of properties according to the rules and criteria set out on the decision of Council of Ministers? Although the provisions of the law 'On restitution and compensation of the property' have often been subject for revision of the constitution, such issue has never been referred to the Constitutional Court. The answer to this question can be found if we refer to constitutional jurisprudence of Lithuania and Hungary. By request for this issue, the Constitutional Court of Lithuania states that:

"the legal provisions which grant the Council of Ministers the competence to determine the procedure, conditions and rules regarding the duration for distribution of compensation, without clearly defining by law the criteria and deadlines for carrying out the compensation, is in conflict with the Constitution, principle of separation of powers and rule of law. (LTU V.19/2, 2005)"

In line with this argument, the Constitutional Court of Lithuania holds the position that it is the duty of the government to determine and allocate sufficient funds to fulfil its obligations according to the criteria and deadlines defined by the law. According to the Court, it is the duty of the legislator that the set criteria and deadlines are in line with those standards such as: clearity, reliability, gurantee and ensuring the legal expectations (ibid). In a similar situation, the Constitutional Court of Hungary(Hungarian Constitutional Court,1991:16) issued a request with subject the anticonstitutionality of the law which was related to splitting into phases the compensation process, has rejected this request as unfounded and not based on arguments, as long as the duration of the process and its content are previously defined clearly by the legislator ( $\mathrm{HCC}$ 16/1991).

The numerous legal measures aimed at the increase of assurances for the execution of decision are completely utopian and do not serve their purpose. In the concept of law and the respective procedures set out by the Council of Ministers, on one hand the legislator considers the PRCA decision for recognition, restitution and compensation of the property as an executive title which must be executed according to the requirements of the Code of Civil Procedures. And, on the other hand that decision must follow the 
chronological turn based on the data of decision for recognition, restitution and compensation of the property. Since the time when such a regulation came into power, no subject has ever executed the decision for recognition, restitute and compensation of the property because the compensation procedures adopted by a sub-law provide different definition (AKKP, Drejtoria e Kompensimit të Pronës, Sektori i Shpërndarjes dhe Vlerësimit të Kompensimeve, 2012)

Since 1998, no fund of other types of immovable properties have been allocated to the physical compensation fund, although the final deadline within which all these procedures must be completed has been postponed several times. The physical compensation fund receives only those types of immovable properties which have remained unsold, after passing all the privatization procedures by the respective state agencies.(VKM nr. 428, 2010:chap. 3/18).

Non implementation of the legal obligations by the compentent state authorities for transferring the incomes from the privatization to the property compensation fund constitutes another problem in this field. The principle of transparency requires the state authorities to make public the data related to their activity. The expropriated subjects must be given the opportunity to be acquainted with the information regarding their own interest. Has the property compensation fund received any transfer of incomes obtained from the auction sale of state assets for which there is no decision from the property restitution and compensation commissions, respectively in the amount of $65 \%$ of the sale value for objects and $100 \%$ of the sale value of plot of land'? ${ }^{1}$ Ligji nr.10239,2010: art. 3/1).Why are not made public the details related to the cash value which correspond to each source foreseen by law and must be transferred continuously to the financial compensation fund? How do the ministry of Finance and Directorate of Administration and Sale of Public Properties implement this? The practice has shown that the massive privatization process which has encompassed the Albanian economy (assets or public properties) has not brought any income to the financial compensation fund.

Another aspect which affects negatively the implementation of the compensation process for the expropriated subjects is the fact that the Albanian government has charged the PRCA the duty of carrying out another process which is related to the compensation of private properties which are expropriated as a result of the legalization process of informal constructions. This unjustifiably increases the workload of the agency and does not help in fulfilling the main objective for which this agency was established.

All these issues indicate that the Albanian authorities must take immediate measures to gurantee the rights gained by the citizens. These measures are indispensable for the rule of law because they serve to maintaining the trust of the citizens to the state ands its laws. Therefore, the government must remove from the legal system the provisions which bring malfunctioning and correct the practices which are in conflict with the law (Broniowski versus Polony nr. 31443/96, 2004).

\subsection{Full or partial compensation}

By proclaiming the concept of fair compensation, the Constitution does not foresee any form how to apply it. According to the definition of the above Constitution(Ligji nr. 8561, 1999, art.4) the fair compensation for properties which are currently being expropriated, can take only the financial compensation form, while in the meaning of the law for restitution and compensation of properties, it can take the form of financial and physical compensation. The standard based on which the fair compensation is evaluated for both expropriated properties is the market value(ibid art.17/2, and Law 9235, 2004:13). But, should this compensation be in full for properties which are compensated to the expropriated subjects the same as if this property was to be expropriated today? It is under the competence and discretion of the legislator to assess whether full compensation shall be given or another compensation scheme must be adopted. For the Albanian legislator, the damage inflicted to the expropriated subjects by unfairly taking their property during the communist regime must be compensated, by engaging the government to the restoration of the property right over the previous property; and if it is not possible, in full compensation of the property according to the market price at the moment of acknowledging this right. 
The ECHR has persistently made known its viewpoint that the countries do not have the duty to compensate in full the expropriated subjects, but it is sufficient if the countries set out compensation schemes which respect the fair balance criterion (Former King of Greece and other against Greece, no. 25701/94 2000). This criterion means that the compensation for the expropriated property must take into consideration two basic principles: proportionality and fair, equal and non-discriminatory treatment of subjects. Under the viewpoint of the first principle, the compensation must be in reasonable proportion in comparison with the value of the property. The reasonable proportion means setting a fair relation between the compensation value and the value of the expropriated property. ( ${ }^{1}$ Pincova and Pinc, Broniowski vs Poland ,2012.

Different form the East and South-East European countries; the Albanian government has held the principle of full compensation of the property (except the agricultural land which is compensated up to $100 \mathrm{ha}$ ). Although the ECHR and Constitutional Court jurisprudence established an important legal basis to sensibilize the legislator to avoid 'extreme' views for full compensation of the property and to draft a legal framework with realistic, tangible and achievable objectives, such a change was never reflected in the respective law. Holding such stance is reflected in the margins the Parliament assessment, which in this case, except the political judgement, must take into consideration also the two important criteria namely economic and legal.

The economic criterion is firstly related with the macroeconomic impact which the compensation bill bears for the expropriated subjects within a reasonable deadline. The payment of such bill undertaken by the Albanian state must not only fulfil the justified expectations of the expropriated subjects but also must not affect the operation of the economic system of the country. Before the legislator embarks on such commitments, it is supposed that he has analyzed and assessed the real possibilities that Albanian state has for carrying out full compensation for each expropriated subjects. In this aspect, to analyze the real capacities of the Albanian state means on the one hand, to have clear analytic indicators with regard to the number of administrative decision (or even court ones which have changed those decisions), number of beneficiary subjects, type of property which is entitled for compensation, the respective areas which are provided for compensation of the expropriated subjects, and on the other hand, to have available and plan financial or physical sources to enable the full compensation under the framework of a defined scheme of actions within the reasonable deadlines. Such an analysis requires time and serious commitment by qualified staff under the conditions where the respective data cannot be easily found at the relevant administrative or court authorities due to the numerous problems that have accompanied the Albanian long transition. Another factor which makes more difficult the analysis process is the fact that the property recognition, restitution and compensation process remains open. Each submitted request but not processed yet, as well as, any right for submitting a new request which has a new deadline through the court, influences the finalization of the accurate total financial bill. In order to perform an accurate assessment of this situation, in general is necessary to have a new stance by the legislator, by aiming to give end to the court overlapping of the right in order to submit a new request to the administrative authorities within a reasonable deadline. This stance is fully justifiable, because it is based not only on the argument that the process of recognition, restitution and compensation of the property is temporary, but also on important principle of the rule of law such as: public interest, judicial assurance, equality, and by not infringing the social justice and the rights of the expropriated subject.

Except the economic criterion, the effective implementation of the compensation process within a reasonable time and fulfilment of the property compensation right in favour of the expropriated subjects serves to the compliance with the legal criterion of legitimacy (which is examined above) and the regular legal process sanctioned by the Constitution of Albania and Eurpean Convent for Protection of Human Rights. The Eurpean Court has noticed the non-execution in time of the decisions with final force and effect, court decision or decisions of the property commissions, which considers them as quasi, infringes the right of the claimants for a fair legal process according to article 6, and the property right according to article 1 of Protocol no 1 of the European Convention. The execution of the decision constitutes a basic element of the rule of law and the notion for fair trial. The execution within a reasonable deadline of decisions with final force and effect (administrative or legal) is intergral part of the right for fair legal process in the meaning of the Constitution and 
article $6 \S 1$ KEDNj-së (Constitutional Court, V.50/2011:234). The execution of the decision with final force and effect is considered as the final phase for achieving a right which is gained in a legal or administrative way. Only after achieving such right, it could be considered that the person has finally fulfilled his right. The process of fulfilling a viloted right includes not only the decision making, but also the concrete actions of the authorities charged with the execution of decisions with final force and effect. Therefore, the state has the positive obligation to organize a system for implementation of decisions (Dashamir Uruci kundër Shqipërisë, 2009:6491/06). This obligation is effective in the legal and practical aspect and the government itself ensures the implementation of the laws without long delays (Ruianu kundër Rumanisë, 2003:34647/97).

\section{Efforts for resolving the property compensation issue}

Penalizing decisions issued by ECHR against Albania, as well as big flux of similar requests addressed to ECHR, forced the Committe of Ministers of European Council to request the Albanian authorities to draw up a tangible action plan for resolving the land property issue and the excecution of decisions with final force and effect.

In this framework, some concrete measures were carried out according to an action plan for resolving the issue of land property. The content of this document identified a range of detailed preliminary actions that would be carried out with the purpose to identify, evaluate and design on digital map each decision made in order to determine a detailed final financial bill. Determining a financial bill, according to the action plan, would enable the establishment of a fair compensation scheme that would be comprised of a number of proportional instalments up to their full settlement, within the deadline (on which all the process would be accomplished). Furthermore, the action plan included a number of procedurial steps that would characterize the financial or physical compensation process (Council of Ministers Decision no. 350/2011, final scheme, point 1-14). With the completion of this preliminary activity, the final compensation scheme would be adopted by law within November 2011. What is most important, the action plan did not specify the financial or physical sources, and the relevant agencies charged to allocate those sources, making this plan unreliable and not realistic.(VKM $350,2011)$ Moreover, this plan did not even identify the sources of funds regarding the required infrastructure for establishing digital database.(ibid art. 1,2). Although the action plan had its deficiencies, it showed that resolving the property compensation issue is related with the adequate institutional seriousness while performing an analytic preliminary work with regard to key apects: assessment of the whole decisions given in past years, and the requests which are under process in defining a financial indicator and financial and physical sources.

The adoption of an interim compensation scheme (VKM 192,2011) which sets fairer criteria than the previous ones was a result of the request of Committee of Ministers of European Commission.(Memorandumi $\mathrm{CH} / \mathrm{Inf} / \mathrm{DH}$ (2010)20) This scheme aimed to ensure continuity of the land compensation process up to the adoption of the final scheme, which would be functional in January 2013(VKM 350, 2011:2697). Furthermore, at this moment it was believed that the Albanian state would have obtained the information about the number of subjects to be compensated and the final bill for this process.(ibid, art. 1,2,). The fact that the Albanian government still continues with the compensation process in cash in year 2012, same as in the previous interim scheme, is a clear indicator about the lack of commitment to finally resolving in fair and serious way the property compensation process (VKM 768, 2012: 8155).

The Albanian government has recently adopted the Inter-sectorial Strategy for Property Right.(VKM $405,2012)$.This strategy does not provide specific concrete legal, institutional, structural measures for carrying out an effective compensation scheme. In the attempt to set realistic objectives, the document admits that the full compensation scheme would be finalized within year 2013, while the process of completing the administrative review of the requests would be accomplished within year 2014. However, how will these strategic objectives be accomplished while there is no structural or substantial change with regard to the activity of property restitution and compensation authorities? Is the distribution of compensation process fair as it is based on rules and criteria that do not treat equally all the expropriated subjects? How does it fulfil the 
social justice principle? How does the development of another interim compensation process support the timely accomplishment of the strategic objective, when it last up to 4 months by law, and do we have sufficient human resources to deal solely with the duty to finalize the final compensation scheme? Each of these rhetorical questions has been answered in this study.

\section{Conclusions and Recommendations}

A legal reform, in a certain field, is considered effective if it integrates its major purposes and orientations with the systems of organizing the sources (human, material and financial), including the contents and activities that should be undertaken. The Albanian authorities admit that the human resources are sufficient for full compensation and there are no objective circumstances to prevent the full compensation of the expropriated subjects who have applied.(ibid art. 1,13) Therefore, the key factor to offer solution to the land property law remains the political commitment, materialized by the strong request of the lawmaker to carry out detailed, fair, non-discriminatory and equal adjustment which enables an efficient performance in practice for each gained right or promise made. But, before this regulation is done, it belongs to the Council of Ministers and other executive authorities of this field to demonstrate serious commitment in making concrete steps in the framework of a well-detailed plan for assessing the situation in detail. Such an analysis would serve to draw up a final compensation scheme which would be fully applicable within appropriate time limits. For Albania, the solution of the land property remains one of the great challenges of the rule-of-law state and an indispensable prerequisite for the European Union integration.

With the intention that this study would, to a certain extent, contribute to the solution of the property compensation issue, I present below some key recommendations that would offer solutions to the issue of land property compensation for the expropriated subjects.

The establishment of a fair compensation scheme must begin with the identification, examination and studying all the statistical indicators of the decisions given in years, which are part of the PRCA archieve or that are present in the archieves of other authorities such as the Archieve Offices of the districts, courts (when the ex-CRCIP decisions are reviewed by the court), LORIP of districts (when the decision processing the property recognized the restitution and has been sent for registration), or the subject himself when the archieves of the municipalities or disctrict councils have been damaged in years (or known as such). This is a formidable task which requires time and qualified and experienced human resources in the field of the property restitution and compensation in order to judge correctly over each final administrative or court decisions which include: type of property that is acknowledged, restituted or compensated (i.e. cadaster item); the overall and respective land area that is restituted or compensated; the location of the property; presentation of the details on a digital map; as well as determining the respective value of the property referred to the method of its assessment.

The completion within the optimal deadlines (foreseen to be finished within 2012) of this duty and moreover, the definition of a fair and proportional compensation scheme through a specific law becomes of great importance for effective performance of the rights obtained.

The implementation of a fair compensation scheme within the aforementioned deadlines means that immediate structural measures shall be taken not only from the so-called Coordination Directorate, but it requires analysed modifications in the structure of the Property Compensation Directorate, part of the Property Restitution and Compensation Agency (PRCA) in order to adapt the workload to be carried out in the framework of finalizing the final compensation bill. In addition, the work of PRCA must be focused in the final verification of the legal status of the immovable properties which are part of the property compensation fund, made available by the Council of Ministers, to check whether they are really unoccupied (free) or whether a third person enjoyes the property rights over them. Also, part of the activity must be the verification and assessment of other properties which passes to the compensation fund after unsuccessful completion of all privatization procedures. 
Simultanously, specific legal and structural measures must be taken to ensure real sources based on which the compensation process will rely. Following the finalization of the final bill, a detailed economic and financial analysis is required over the real capacity of the Albanian government to support with financial or bond funds the compensation process. Besides, a huge task must be carried out by a number of state authorities which administer the state property to ensure that the land and state objects fund which will be transferred to the property physical compensation fund. This delicate process, in addition to improvement of the legal framework, requires a high degree of sensibility and responsibility by relevant executive authorities.

\section{References}

Aquinas, T., (1947). Summa Theologica. English translation by Fathers of the English Dominican Province, in three volumes (New York: Benziger Bros).

Benussi, B. (1931). Komentar i Kodit Civil, Mbrothësija - Kristo P. Luarasi, Tiranë.

Beshiri kundër Shqipërisë No 7352/03 § 61, http://www.avokaturashtetit.gov.al//index.php?option=com_content \&view=article\&id=51:ceshtja-beshiri-etj-kunder-shqiperise\&catid=12:gjendnj\&ltemid=30, retrieved 15. Nov 2012.

Boyce, B. (2007). Property as Natural Right and as Conventional Right in Constitutional Law, 29 Loy. L.A. Int'I \& Comp. L. Rev. 201.

Broniowski v. Poland [GC], 31443/96, §125, ECHR 2004-V. https://wcd.coe.int/ViewDoc.jsp?id=923573\&Site=COE, retrieved 16 Nov 2012

Carss-Frisk, M. (2001). A guide to the implementation of Article 1 of Protocol to the European Convetion on Human Rights.

Dashamir Uruci kundër Shqipërisë, Nr.6491/06. http://hudoc.echr.coe.int/sites/eng/pages/search.aspx?i=001-110761, retrieved 14 Nov 2012.

De Soto, H, Cheneval, F. (2006). Property Rights as Human Rights, Rüffer \& Rub, Zurich.

European Convention on Human Rights, http://www.echr.coe.int/NR/rdonlyres/D5CC24A7-DC13-4318-B4575C9014916D7A/0/Convention ENG.pdf, Retrieved 14 Nov 2012.

Gomien, D. (2005). Udhëzues i shkurtër i Konventës Evropiane për të Drejtat e Njeriut, Gent Grafik, Këshilli i Evropës.

Hayek, F. (1991). The Road to Serfdom, University of Chicago Press.

Hungarian Constitutional Court, AB 16/1991, 952/A/1991, http://www.mkab.hu/admin/data/file/739_16_1991.pdf, retrieved 15 Nov 2012

Ish-Mbreti i Greqisë dhe të tjerë kundër Greqisë, [GC], nr. 25701/94, § 60, ECHR 2000-XII, https://wcd.coe.int/ViewDoc.jsp?id=9841237\&Site=COE, retrieved 17 Nov 2012.

Kodi Civil i Republikës së Shqipërisë, Flet. Zyrt. Nr.11, Fq.491.

Kopecky v. Slovakia [GC], No 44912/98, § 35

Kuti, C. (2009). Post-Communist Restitution and the Rule of Law, CEU Press.

Kushtetuta e Republikës së Shqipërisë, Flet. Zyrt. Nr.28, Fq.1073.

Ligji nr.9235, datë 29.07.2004 "Për kthimin dhe kompensimin e pronës", Flet. Zyrt. Nr.61, Fq.3934.

Ligji nr.7491, datë 29.04.1991"Për dispozitat kryesore kushtetuese", Flet. Zyrt. nr.4, Fq 145.

Ligji nr.7698, datë 15.04.1993 "Për kthimin dhe kompensimin e pronave ishpronarëve", Flet. Zyrt. nr.5, Fq 346.

Ligji nr.10239, datë 25.02.2010, "Për krijimin e fondit special të kompensimit të pronave" Flet.Zyrt. nr.30, Fq 1007.

Ligji nr.9684, datë 06.02.2007 "Për disa shtesa dhe ndryshime në ligjin nr. 9235, datë 29.07.2004"Për kthimin dhe kompensimin e pronës" të ndryshuar, Flet. Zyrt. Nr.11, Fq 182.

Ligji nr.7501, datw 19.07.1991 "Pwr tokwn", Flet. Zyrt. Nr.5, Fq.246.

Ligji nr. 8561, datë 22.12.1999 "Për shpronësimet dhe marrjen në përdorim të përkohshëm të pasurisë pronë private për interes publik", Flet. Zyrt. Nr.37, faqe 1522.

Ligji "Për përmbushjen e të drejës së kompensimit për pasuritë e paluajtshme që u lanë jashtë kufirit aktual të shtetit polak".

LTU-2005-2-005, Vendimi nr.19/02, datë 23.08.2005.

http://www.codices.coe.int/NXT/gateway.dll/CODICES/full/eur/tu/eng/tu-2005-2-005?fn=documentframe.htm\$f=templates\$3.0, retrieved 15 Nov 2012.

Memorandumi $\mathrm{CH} / \mathrm{Inf} / \mathrm{DH}$. (2010). 20, datë 25 maj 2010 i Komitetit të Ministrave të Këshillit të Evropës për masat strategjike për situatën e pronave në Shqipëri

http://www.coe.int///dghl/monitoring/execution/Source/Documents/HRTF/Memo(2010) 20_ALB.pdf, retrieved 15 Nov 2012.

Memorandumi CM/Inf/DH. (2011). 36, 16 Gusht 2011 i Komitetit të Ministrave të Këshillit të Evropës për masat strategjike për situatën e pronave në Shqipëri 
http://www.coe.int/t/dghl/monitoring/execution/Source/Documents/HRTF/Memo(2011) 36_ALB.pdf, retrieved 15 Nov 2012. Rawls, J. (2001). Justice as Fairness: A Restatement ed. Erin Kelly (Cambridge, MA: Harvard University Press).

Ruianu kundër Rumanisë, Nr. 34647/97, 17 qershor 2003,

http://hudoc.echr.coe.int/sites/eng/pages/search.aspx?i=001-134089, retrieved 15 Nov 2012.

Universal Declaration of Human Rights. (2012, November 29). In Wikipedia, The Free Encyclopedia. Retrieved 21:43, November 14 , 2012, from http://en.wikipedia.org/w/index.php?title=Universal_Declaration_of_Human_Rights\&oldid=525481147

Vendimi nr.P1.US1/98, datë 22.09.1998 i Gjykatës Kushtetuese të Republikës Çeke.

Vendimi nr.4, datë 08.04.1994, Gjykatës Kushtetuese të Republikës së Shqipërisë, Flet. Zyrt. Nr.5, Fq 284.

Vendimi nr.7, datë 14.09.1994 i Gjykatës Kushtetuese të Republikës së Shqipërisë, Flet. Zyrt. Nr.17, Fq 817.

Vendimi nr.30, datë 01.12.2005 i Gjykatës Kushtetuese të Republikës së Shqipërisë, Flet. Zyrt. nr.92, Fq 2963.

Vendimi nr.27, datë 26.05.2010, i Gjykatës Kushtetuese të Republikës së Shqipërisë, Flet. Zyrt. nr.81, Fq 7272.

Vendimi nr.50, dt 22.11.2011, i Gjykatës Kushtetuese të Republikës së Shqipërisë, Flet. Zyrt. 234, Fq.4536.

Vendimi Unifikues i Gjykatës së Lartë nr.6, datë 24.01.2007, Flet. Zyrt. Nr.97, faqe 2767.

Vendimi Unifikues i Gjykatës së Lartë nr.23, datë 01.04.2002, Flet. Zyrt. Nr.20, faqe 652.

Vendim nr.183, datë 28.04.2005 "Për miratimin e metodikës për vlerësimin e pronës së paluajtshme që do të kompensohet dhe asaj që do të shërbejë për kompensim", Flet. Zyrt. Nr.33, Fq. 1219.

VKM nr.567, datë 05.09.2007 "Për miratimin e kritereve dhe procedurave, për caktimin e pronave, fond pasurie të paluajtshme, për kompensim fizik".

VKM nr.868, datë 18.06.2008 "Për krijimin e fondit të kompensimit fizik nga fondi i tokës bujqësore", Flet.Zyrt. Nr.138. Fq 6123.

VKM nr.1077, datë 18.06.2008"Për krijimin e fondit të kompensimit fizik nga fondi pyjor dhe kullosor", Flet.Zyrt. Nr.129, Fq 5707.

VKM nr.1232, datë 18.06.2008 "Për krijimin e fondit të kompensimit nga objektet shtetërore", Flet. Zyrt. Nr.147, Fq 7264.

VKM nr.1696, datë 24.12.2008 "Për krijimin e fondit të kompensimit fizik, nga objekte shtetërore të "Albminiera"sh.a, dhe të Shërbimit Gjeologjik Shqiptar", Flet. Zyrt.Nr.206, Fq 11089.

VKM nr.566, datë 23.08.2006 "Për organizimin dhe funksionimin e Agjencisë së Kthimit dhe Kompensimit të Pronave", Flet. Zyrt. Nr.94, Fq.3938.

VKM nr.256, datë 13.04.2010 "Për organizimin dhe funksionimin e Agjencisë së Kthimit dhe Kompensimit të Pronave", Flet. Zyrt. Nr.56, Fq.2116.

VKM nr.758, datë 16.11.2006 "Për miratimin e procedurave të shpërndarjes së fondit të kompensimit në të holla, për vitin 2006", Flet. Zyrt. Nr.121, Fq.4839.

VKM nr.566, datë 05.09.2007 "Për miratimin e procedurave të shpërndarjes së fondit të kompensimit në të holla, për vitin 2007", Flet. Zyrt. Nr.119, Fq.3394.

VKM nr.1343, datë 04.06.2008 "Për miratimin e procedurave të shpërndarjes së fondit të kompensimit të pronarëve, në të holla, për vitin 2008", Flet. Zyrt. Nr.158, Fq.7750.

VKM nr.487, datë 06.05.2009 "Për përcaktimin e rregullave dhe të kritereve të shpërndarjes së fondit të kompensimit të pronarëve, në të holla, për vitin 2009", Flet. Zyrt. Nr.82, Fq.3607.

VKM nr.192, datë 09.03.2011 "Për përcaktimin e rregullave dhe të kritereve për shpërndarjen e fondit të kompensimit, pronarëve, në të holla, për vitin 2011", Flet. Zyrt. Nr.22, Fq.815.

VKM nr.768, datë 07.11.2012 "Për përcaktimin e rregullave dhe të kritereve për shpërndarjen e fondit të kompensimit, pronarëve, në të holla, për vitin 2012", Flet. Zyrt. 148, faqe 8155.

VKM nr.428, datë 09.06.2010 "Për kriteret e vlerësimit të pronës shtetërore, që privatizohet, apo transformohet, dhe për procedurën e shitjes", "Për organizimin dhe funksionimin e Agjencisë së Kthimit dhe Kompensimit të Pronave", Flet. Zyrt. Nr.83, Fq.4333.

VKM nr.350, datë 29.04.2011 "Për miratimin e planit të veprimit për zgjidhjen e problematikës së çështjeve të pronësisë, e identifikuar në Memorandumin e Komitetit të Ministrave të Këshillit të Evropës", Flet. Zyrt 67, faqe 2697.

VKM nr.405, datë 27.06.2012 "Për miratimin e strategjisë ndërsektoriale, Reforma në fushën e të drejtave të pronësisë 2012-2020, si dhe planit të veprimit të saj", Flet. Zyrt. Nr.86, Fq.4327.

Von Maltzan and Others v. Germany (dec.) [GC], No 71916/01, 71917/01 dhe 10260/02, § 74, ECHR 2005-V, http://hudoc.echr.coe.int/sites/eng/pages/search.aspx?i=001-130434, retrieved 14 Nov 2012.X 
